\title{
A solid phase radioimmunoassay for detection of early pregnancy in the South Indian bonnet monkey Macaca radiata
}

\author{
R. CHAKRABARTI, G. S. MURTHY and A. JAGANNADHA RAO \\ Department of Biochemistry, Center for Advanced Research in Reproductive Biology \\ (ICMR), Indian Institute of Science, Bangalore 560 012, India
}

MS received 28 December 1984

\begin{abstract}
Using an antibody raised in the rabbit to ovine leutenizing hormone $\beta$ subunit coupled to activated cellulose, a solid phase radioimmunoassay to detect early pregnancy in the South Indian bonnet monkey has been developed. Non-specific inhibition due to serum was eliminated by inclusion of new born calf serum in the assay tubes. The assay is simple, needs only one centrifugation and can be completed in $6 \mathrm{~h}$ at room temperature with no false positive results.
\end{abstract}

Keywords. Chorionic gonadotropin; monkey; solid phase assay; ovine leutinizing hormone; antiserum.

\section{Introduction}

Several methods have been reported for detection of pregnancy in the non-human primates. These include estimation of the levels of estrogen and progesterone in successive serum samples till 28th day of menstrual cycle from a female following exposure to a proven fertile male (mated-cycle) (Hendrickx et al., 1978), testing for the presence of chorionic gonadotropin $(\mathrm{CG})$ in urine using the mouse uterine weight assay (Wilson et al., 1970) or the non-human primate hemagglutination inhibition assay for CG (Hodgen et al., 1974a). Though these methods are simple to operate they are not sensitive, specific and are time consuming and expensive. The development of a specific radioimmunoassay to monitor serum $\mathrm{CG}$ in non-human primates has greatly facilitated studies using monkey as an experimental animal model system (Hodgen et al., 1974b; Atkinson et al., 1975). Recently we have also reported the development of a simple and specific radioimmunoassay to monitor serum $C G$ in the bonnet monkey using antiserum to ovine leutinizing hormone $\beta$ subunit $(\mathrm{oLH} \beta)$ (Rao et al., 1984). While these radioimmunoassay methods are quite specific, they still need about 24 to $30 \mathrm{~h}$ for completion. Though this duration is quite normal and acceptable in radioimmunoassays, in view of the very short period during which CG is detectable during pregnancy in monkeys, any further reduction in time needed for detection of

Abbreviations used: CG, Chorionic gonadotropin; oLH, ovine leutinizing hormone; hCG, human CG; DEAE, diethylaminoethyl; BSA, bovine serum albumin; RIA, radioimmunoassay; NCS, new born calf serum. 
pregnancy will greatly facilitate design of experiments involving pregnant monkeys. In the present communication we report the adaptation of a liquid phase radioimmunoassay for monitoring serum CG to a solid phase system using the easily available cellulose as a matrix.

\section{Materials and methods}

The details of maintenance, breeding of monkeys, characterization, specificity and cross-reactivity of the antiserum used in the development of liquid phase radioimmunoassay has been described in an earlier study (Rao et al., 1984). The day on which vaginal bleeding was first noticed was considered as day 1 of the menstrual cycle. Blood samples were collected without the use of anaesthesia and serum was separated within $24 \mathrm{~h}$ and the samples stored at $-20^{\circ} \mathrm{C}$ until further processing. For breeding purposes, female bonnet monkeys were housed in the cage of proven fertile males from day 9 until day 14 of the menstrual cycle. For detection of pregnancy 100-200 $\mu \mathrm{l}$ of serum samples on day 28-30 of mated-cycle were used. Iodination of hCG (CR-123 gift from NIH, USA) was done by chloramine-T method (Greenwood et al., 1963) and the specific activity ranged from $40-50 \mu \mathrm{Ci} / \mu \mathrm{g}$. All other reagents were of analytical grade obtained locally.

\section{Coupling of oLHß antibody to cellulose}

Immunoglobulin enriched fraction from antiserum to $\mathrm{oLH} \beta$ raised in rabbits was prepared using diethylaminoethyl (DEAE)-cellulose chromatography (Fahey and Horbett, 1959).

Activation of cellulose was done according to the procedure described earlier (Murthy and Moudgal, 1983). The coupling procedure consisted of adding $2 \mathrm{ml}$ of $0.2 \mathrm{M}$ sodium phosphate buffer ( $\mathrm{pH} 6 \cdot 5)$ to $50 \mathrm{mg}$ of epoxy-activated cellulose followed by $0.1 \mathrm{ml}$ of $\gamma$-globulin (isolated from antiserum to $\mathrm{oLH} \beta$ ) solution $(1.35 \mathrm{mg} / \mathrm{ml}$ ) and $0 \cdot 1 \mathrm{ml}$ of $1 \mathrm{M}$ sodium carbonate solution. The mixture was allowed to stand at room temperature overnight with constant stirring. The cellulose-suspension was washed extensively with $0.2 \mathrm{M}$ sodium phosphate buffer $(\mathrm{pH} 6.5)$ and the final pellet was reconstituted in a $2 \mathrm{ml}$ of $0.05 \mathrm{M}$ sodium phosphate buffer containing $0.15 \mathrm{M} \mathrm{NaCl}$ and 0.038 M EDTA, containing $2 \%$ bovine serum albumin (BSA) and used for further experiments. The quantity of $\gamma$-globulin coupled to cellulose was determined by estimating the protein in the cellulose suspension, before suspending it in buffer containing $2 \%$ BSA. For protein estimation a known quantity of $\gamma$-globulin coupled cellulose suspension was washed extensively with double distilled water and finally with acetone. The dry pellet was suspended in $0 \cdot 1 \mathrm{~N} \mathrm{NaOH}$ after ascertaining its weight. Protein was estimated by Lowry's method (Lowry et al., 1951) using rabbit $\gamma$-globulin as a standard, As a control an equal quantity of uncoupled cellulose was processed exactly in the same way as described above. Absorbance of the clear supernatant obtained after centrifugation at 2,000 $\mathrm{g}$ for 30 min was determined at $680 \mathrm{~nm}$.

The ability of the cellulose coupled antibody to bind $\left[{ }^{125} \mathrm{I}\right]$-labelled hCG was ascertained by incubating a suitably diluted cellulose suspension with $\left[{ }^{125} \mathrm{I}\right]$-hCG (20-25,000 cpm), in 0.05 M sodium phosphate buffer containing $0.15 \mathrm{M} \mathrm{NaCl}, 0.038 \mathrm{M}$ 
EDTA and 0.2\% BSA (radioimmunoassay (RIA) buffer], at room temperature for $6 \mathrm{~h}$ followed by addition of $1 \mathrm{ml}$ of RIA buffer and centrifugation in cold by 2,000 $\mathrm{g}$ for $20 \mathrm{~min}$. The supernatant was poured of and radioactivity in the pellet was determined in Packard Priyas counter. Optimal time for incubation was determined by processing sets of tubes at different time points. The non-specific inhibition due to serum interference was evaluated by checking the binding of cellulose coupled antibody to $\left[{ }^{125} \mathrm{I}\right]$-hCG in presence of sera from a variety of species. Sera used for checking nonspecific binding are from pooled batches. For routine application to detect CG in serum of pregnant monkeys $2.5 \mu$ l cellulose suspension in $0.1 \mathrm{ml}$ of RIA buffer was incubated with known quantity of unlabelled hCG or with different aliquots of monkey serum and $\left[{ }^{125} \mathrm{I}\right]$-labelled hCG at room temperature for $6 \mathrm{~h}$. At the end of incubation, $1 \mathrm{ml}$ of RIA buffer was added to each tube and centrifuged at 2,000 $\mathrm{g}$ in cold, supernatant was poured off and the radioactivity in the pellet was determined.

\section{Results}

Protein estimation studies revealed that $56-59 \%$ of added protein $(\gamma$-globulin enriched fraction) was coupled to the activated cellulose. Based on this it is estimated that each tube received $0.09 \mu \mathrm{g}$ of protein which approximately represents $0.010 \mu \mathrm{l}$ of original antiserum representing a dilution of 1:10,000 of original antiserum. The data presented in figure 1 shows that an amount as low as $0.035 \mu \mathrm{g}$ of antibody protein coupled to cellulose was able to bind a significant quantity of $\left[{ }^{125} \mathrm{I}\right]-\mathrm{hCG}$ and there was a linear increase in binding with increasing amounts of the antibody. For routine use, $2.5 \mu 1$ of antibody-cellulose suspension, representing $0.09 \mu \mathrm{g}$ of protein, was used. It can be seen from figure 2 that the optimal time of incubation was found to be $6 \mathrm{~h}$ and incubation at

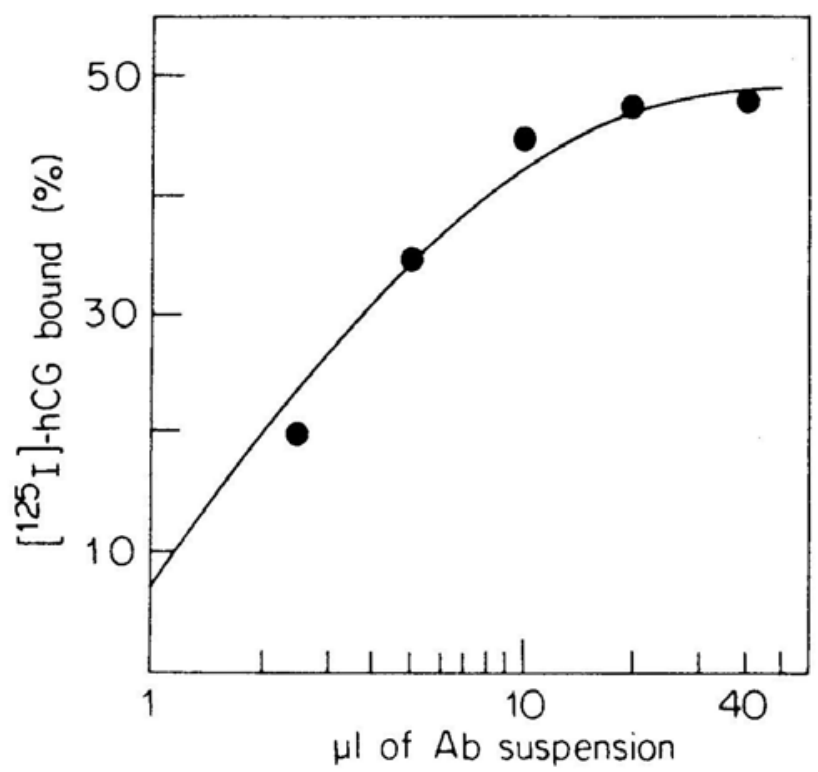

Figure 1. Dose response curve with cellulose coupled oLH $\beta$ antibody to bind $\left[{ }^{125} \mathrm{I}\right]-\mathrm{hCG}$. 


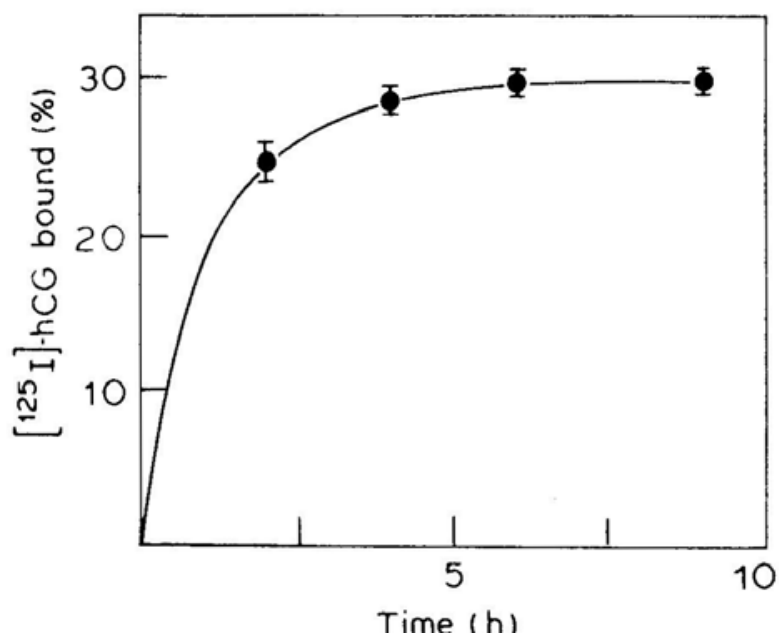

Figure 2. Time course of incubation with cellulose coupled oLH $\beta$ antibody to bind $\left[{ }^{125} \mathrm{I}\right]$ hCG. $2 \cdot 5 \mu 1$ of cellulose coupled antibody was added to each tube.

room temperature or at $37^{\circ} \mathrm{C}$ did not alter the slope of the inhibition plot (figure 3). A typical inhibition plot obtained is presented in figure 4 . The range of the standard curve was $0.25 \mathrm{ng}$ to $10 \mathrm{ng}$ and the minimal detectable quantity of hCG was $0.5 \mathrm{ng} / 0 \cdot 1 \mathrm{ml}$. The data presented in figure 4 clearly shows that pregnant monkey serum exhibited parallel inhibition with hCG. Also, as expected, the serum from day 33 showed maximum inhibition compared to day 30 of a fertile cycle. It was shown earlier (Rao et al., 1984) that in bonnet monkey, the serum CG reached peak values by day 33-35 of fertile cycle. However, during routine application of the assay to serum samples it was

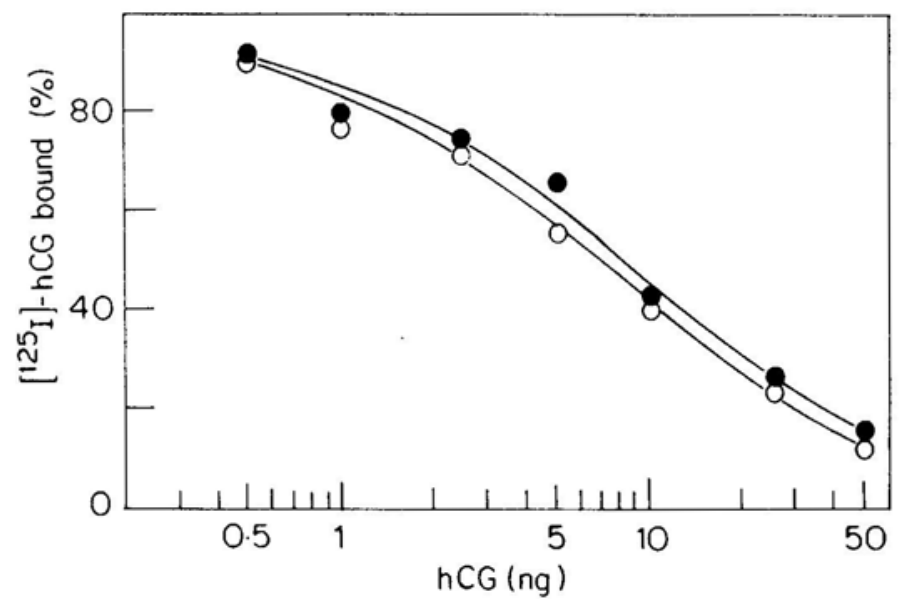

Figure 3. Effect of incubation temperature on the standard inhibition plot. (•)., At $37^{\circ} \mathrm{C}$ for $6 \mathrm{~h}$. (०), At room temperature for $12 \mathrm{~h}$. 


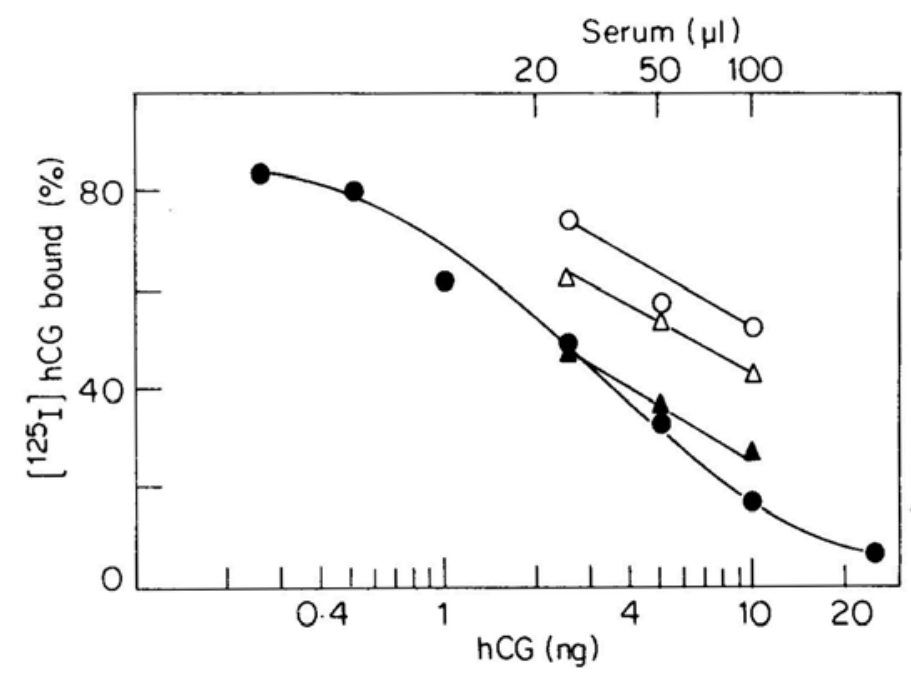

Figure 4. Inhibition plot for $(\bullet)$ hCG and pregnant monkey serum (o, day $30 ; \Delta$, day $31 ; \boldsymbol{\Delta}$, day 33 of fertile cycle).

observed that dose dependent inhibition of $\left[{ }^{125} \mathrm{I}\right]-\mathrm{hCG}$ binding was observed even in the presence of serum from normal or gonadectomized male or female monkeys. It should be pointed out that the $\mathrm{oLH} \beta 3$ antibody used for coupling was earlier thoroughly characterized for developing a liquid phase assay (Rao et al., 1984) and serum from normal or gonadectomized male or female monkeys did not interfere in liquid phase assay when carried out in the presence of bovine serum. This suggested the possibility that the observed displacement was probably a non-specific one and the identical slopes $(-6 \cdot 4$ to $-7 \cdot 6)$ of the standard curve in the presence of different sera from various species, confirms this suggestion (figure 5). A detailed study indicated that the nonspecific displacement was due to $\gamma$-globulin in the serum. The results presented in figure 6 indicate that, of the four proteins namely BSA, cytochrome-C, total protein of new born calf serum (NCS) and purified $\gamma$-globulin tested, only total protein from NCS and $\gamma$-globulin were effective in causing a dose dependent inhibition, and the purified $\gamma-$ globulin was more effective than the whole serum protein. In order to overcome this, non-specific interference, $100 \mu \mathrm{l}$ of pooled NCS was included in all the standard assay tubes and in the sample tubes the total serum concentration was kept constant (100 $\mu \mathrm{l})$ by adding appropriate amount of same serum. The data presented in figure 7 clearly indicates that while in the absence of NCS, gonadectomised as well as normal or pregnant monkey serum show parallel displacement, in the presence of NCS, only pregnant monkey serum showed dose dependent displacement. In view of this, for routine use, in all assay tubes serum concentration was kept constant $(100 \mu l)$ and application of the assay to samples from mated cycles revealed that pregnancy could be successfully diagnosed with no false positives. Of the total number of samples tested there were six true positive and 19 true negative and only one false negative and no false positives. Of those diagnosed to be positive for CG, pregnancy was ascertained by rectal palpation and delivery of the young in all the animals (table 1). 


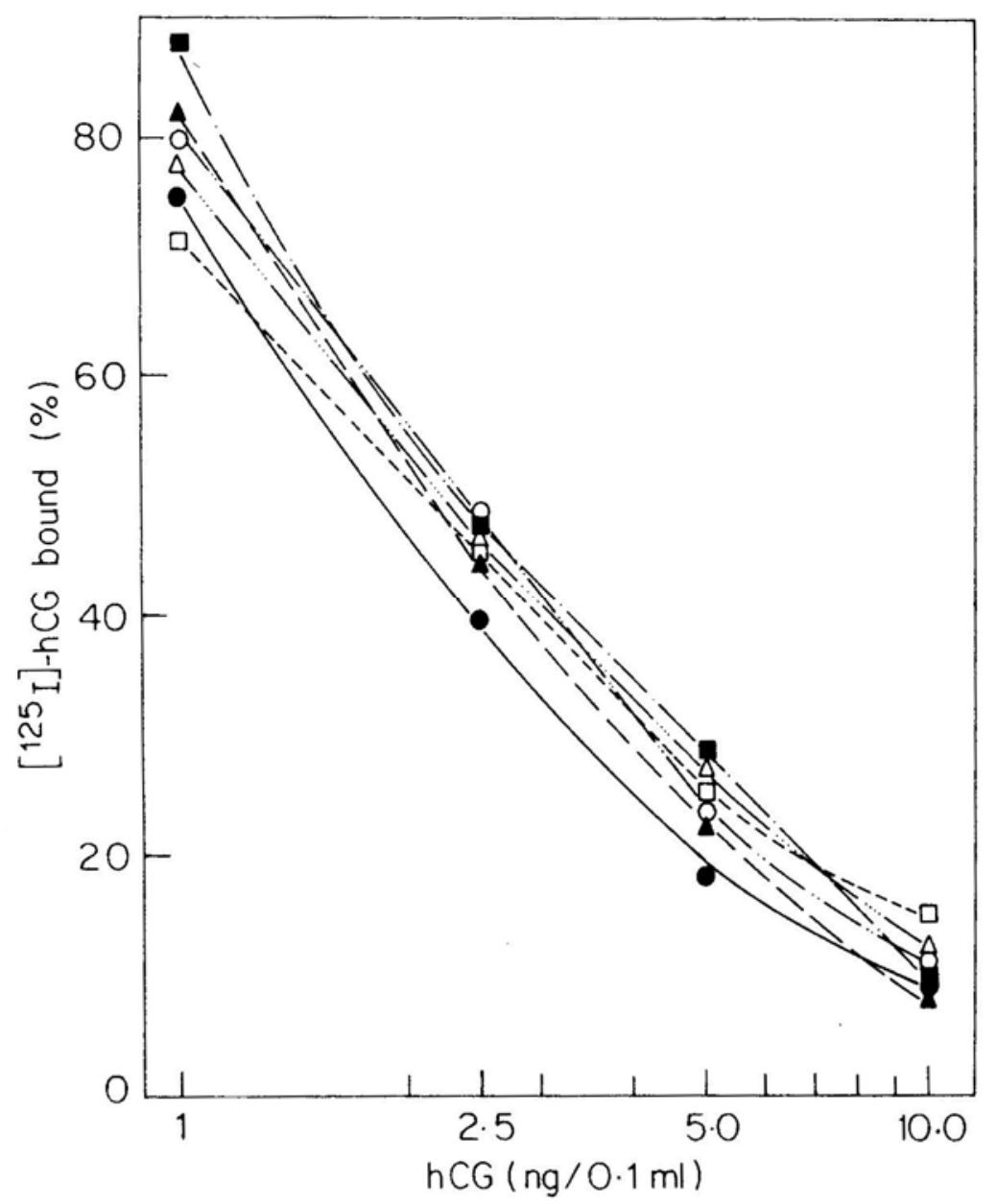

Figure 5. Effect of incubation in presence of serum from different species of animals on $\left[{ }^{125} \mathrm{I}\right]-\mathrm{hCG}$ binding to cellulose coupled oLH $\beta$ antibody. (ם), Normal monkey serum. ( $\Delta$ ), Normal goat serum, (o) Normal rat serum. ( $\Delta$ ), Normal rabbit serum. ( $\square$ ), Castrate monkey serum. (•), No serum. $100 \mu$ of serum was added per tube.

\section{Discussion}

One of the primary requirements in investigating problems in reproductive physiology of primates is the availability of non-human primates of dated pregnancy. This is particularly essential in studies involving development and evaluation of new contraceptives. All the methods thus far reported are based on the tests for detection of CG in urine or serum and now-a-days it is routinely done by RIA, which takes at least $24 \mathrm{~h}$ for completion. However, Booher et al. (1983) have recently reported, on the application of commercially available human pregnancy test kit using bovine corpus luteum membrane receptor preparation for detecting pregnancy in Rhesus monkeys. 


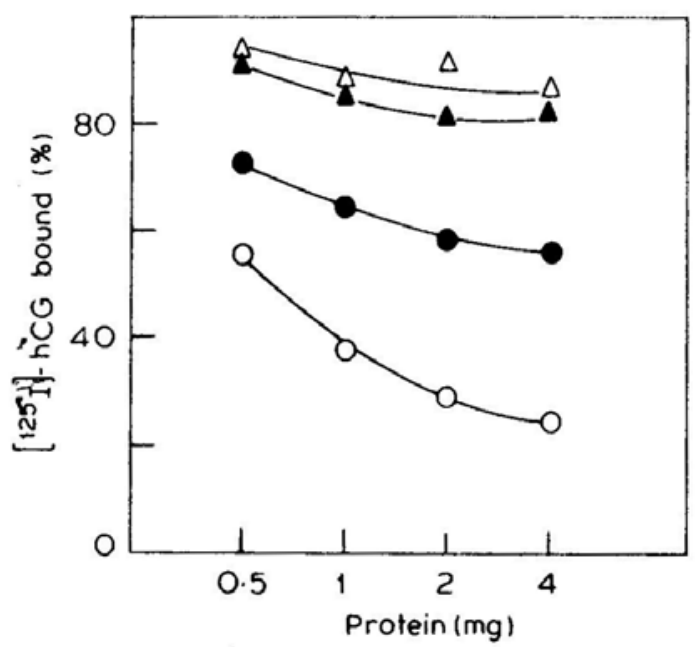

Figure 6. Effect of addition of $(\Delta)$, Cytochrome-C; $(\boldsymbol{\Delta})$, Bovine serum albumin; $(\bullet)$ Total serum proteins from new born calf serum, and (o) Bovine $\gamma$-globulin on $\left[{ }^{125} \mathrm{I}\right]-\mathrm{hCG}$ binding to cellulose coupled oLH $\beta$ antibody.

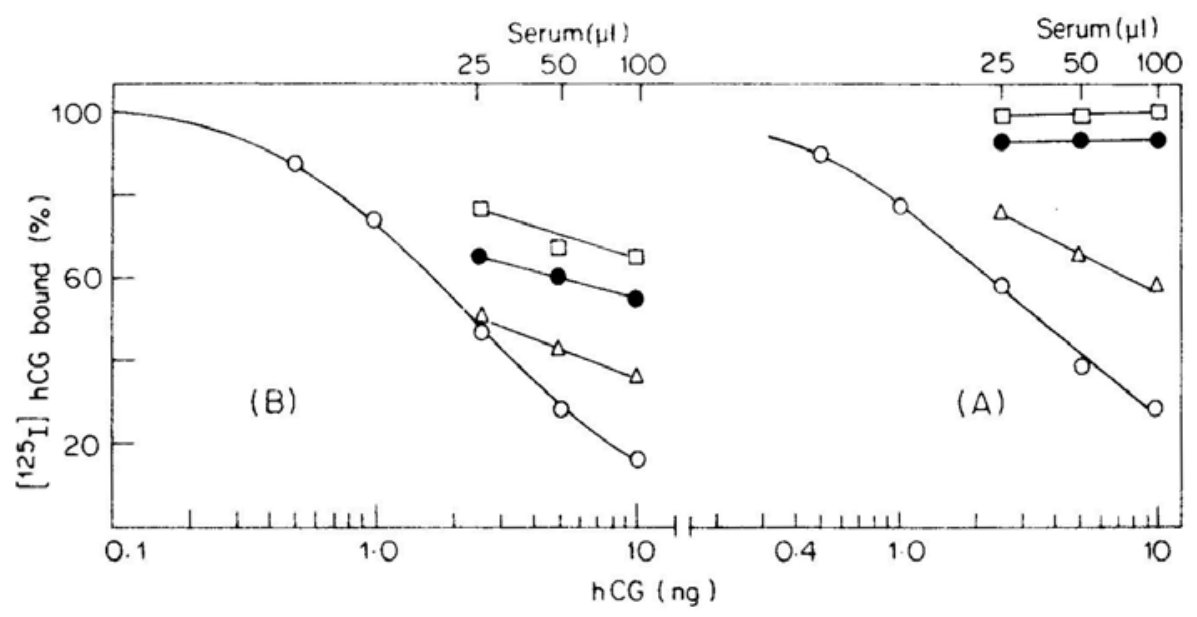

Figure 7. hCG inhibition plot in the absence (B) and presence (A) of bovine serum, (o), hCG; $(\Delta)$, serum from pregnant monkey; $(\bullet)$, castrate monkey serum; $(\square)$, normal monkey serum.

Table 1. Application of the solid phase RIA for detection of pregnancy in the bonnet monkey*

\begin{tabular}{ccccc}
\hline $\begin{array}{c}\text { Total No. } \\
\text { of tests }\end{array}$ & $\begin{array}{c}\text { True } \\
\text { positive }\end{array}$ & $\begin{array}{c}\text { True } \\
\text { negative }\end{array}$ & $\begin{array}{c}\text { False } \\
\text { positive }\end{array}$ & $\begin{array}{c}\text { False } \\
\text { negative }\end{array}$ \\
\hline 26 & 6 & 19 & Nil & 1 \\
\hline
\end{tabular}

* Serum between 28-30 day of fertile cycle was used in the assay. 
This assay is highly reproducible with minimal false negatives and with no false positives and needs only $90 \mathrm{~min}$ for completion. Thus while this assay appears to be quite simple and quick, it needs the procurement of commercial reagents. However, the present assay developed by us can be standardised very easily and the cellulose coupled antibody is quite stable under laboratory conditions. The cellulose coupled antibody can be stored for at least 3 months in RIA buffer containing $2 \%$ BSA at $4^{\circ} \mathrm{C}$ without appreciable loss of activity. In addition, the procedure is simple, needs only $6 \mathrm{~h}$ and only one centrifugation. The reason for non-specific inhibition due to $\gamma$-globulin is not clear at the moment. However, with the inclusion of NCS this assay can be applied to monkey sera without any interference from other serum proteins and the occurrence of false positive which is frequent when large volumes of sera are tested is completely eliminated. Though the specific binding is slightly decreased in the presence of NCS or inclusion of large volumes of test sample, this does not interfere with the detection of pregnancy. In view of the fact that $\mathrm{CG}$ is detectable in significant quantities for only a short duration in monkeys, the available period for actual experimentation for studies involving CG determination is very restricted, particularly those concerned with regulation of CG secretion or biosynthesis of CG. It is hoped that the availability of a simple and rapid test to detect pregnancy in monkey will greatly facilitate the design of experiments as well as use of experimental animals with maximum efficiency, and considerable expenditure otherwise incurred in monitoring steroid levels and maintenance of monkeys will be reduced.

\section{Acknowledgements}

The authors wish to thank Dr. N. R. Moudgal for his constant encouragement and Dr. N. Ravindranath, Mr. B. Shanmugavelu and Mr. S. G. Kotagi and Mr. M. Srinath for technical assistance and Family Planning Foundation, Indian Council of Medical Research for financial assistance and World Health Organization for assistance by way of small supplies programme to Dr. N. R. Moudgal.

\section{References}

Atkinson, L. E., HotchKiss, J., Fritz, G. R., Surve, A. H., Neil, J. D. and Knobil, E. (1975) Biol. Reprod., 12, 335.

Booher, G. B., Prahalada, S. and Hendrickx, A. G. (1983) Am. J. Primatol., 4 , 45.

Fahey, J. L. and Horbett, P. (1959) J. Biol. Chem., 10, 235, 2645.

Greenwood, F. C., Hunter, N. M. and Glover, J. S. (1963) Biochem. J., 89, 114.

Hodgen, G. D. and Ross, G. T. (1974a) J. Clin. Endocrinol. Metab., 38, 927.

Hodgen, G. D., Tullner, W. W., Vaitukaitis, J. L., Ward, D. N. and Ross, G. T. (1974b) J. Clin. Endocrinol. Metab., 39, 457.

Hendrickx, A. G., Thompson, R. S., Hess, D. L. and Prahalada, S. (1978) Symp. Zool. Soc. London, 43, 219. Lowry, O. H., Roseburgh, N. J., Farr, A. L. and Randall, R. J. (1951) J. Biol. Chem., 193, 265.

Murthy, G. S. and Moudgal, N. R. (1983) 52nd Annual Meeting of Society of Biological Chemists, India, Abs. No. 555 .

Rao, A. J., Kotagi, S. G, and Moudgal, N. R. (1984) J. Reprod. Fert., 70, 449.

Wilson, J. G., Frodkin, R. and Hardman, A. (1970) Teratology, 3, 59. 